\title{
When Does Implementation of Relationship Orientation in New Product Launch Matter?
}

\author{
Paul Viio* \\ Dr.Sc. (Econ.), Director sales research \\ Department of Marketing, CERS - Centre for Relationship Marketing and Service \\ Management, Hanken School of Economics, PO Box 479, FIN-00101 Helsinki, \\ Finland \\ paul.viio@hanken.fi \\ Tel.: +358458476337 \\ Fredrik Nordin \\ Associate Professor of \\ Department of Marketing, Stockholm Business School, Stockholm University, \\ Roslagsvägen 101, Building 7, SE-106 91 Stockholm, Sweden \\ fn@sbs.su.se \\ Tel. +468163309
}

*Corresponding author

\section{Introduction}

Relationships has been a central theme in marketing for a long time, both for academics and practitioners. Matikainen, Terho, Matikainen, Parvinen and Juppo (this issue) contribute another piece to this area by investigating how relationship orientation (RO) adopted by the sales force in their activities influences the launch of the product and whether the product is accepted by the customer. While this fundamental idea is very much in line with what has been presented in other articles (see, e.g., Cooper, 1998; Di Benetto, 1999; Hultink \& Atuahene-Gima, 2000; Langerak, Hultink, \& Robben, 2004), their focus is more specific and their hypotheses are tested empirically. In short, they conclude that a firm's RO, which is operationalized through the activities related to sales 
force management (SFM) and relationship leveraging (RL), positively relates to customer acceptance (CA) and success in new product launch (NPL). The article thus contributes with interesting new knowledge, but also raises some questions and ideas for future research. While we agree with the central ideas in the article, we also wonder when the results are valid, e.g., in which industries and market conditions, and how the RO can be applied more specifically in sales. Hence, in the following commentary we discuss their framework in terms of its relevancy in various contexts and the more concrete application of it. Avenues for further research are also suggested.

\section{Contextualizing the applicability of relationships in sales}

The fundamental conclusion of their article is that a relationship orientation in the sales function during the NPL phase will be beneficial, something which the respondents in their sample from the pharmaceuticals industry confirmed. The argument put forth is that it will increase CA, and consequently the success of the product launch. However, one should not forget that markets and industries may look very different, e.g., with different degrees of competition, different levels of product complexity, different degree of maturity of the customers, and different degrees of market regulation. It was emphasized already by Borden (1964), one of the pioneers of the often criticized marketing mix concept, that marketing and its ingredients, including personal selling, should be adjusted to various market forces, including government regulations, competitor behavior, and buyer behavior. It would seem logical that success factors, including the relevancy of relationships, for NPL on highly regulated markets, monopolies, markets for simple products, for instance, differ from success factors on other kinds of markets. Furthermore, Di Benedetto (1999) contended that the timing of the launch is just as important as the tactical marketing and selling activities that are performed. Additionally, it seems logical to assume that the effects of and need for RO could differ depending on the novelty and complexity of the launched product. Moreover, the significance and anticipated value of the product for the buyer could affect the need for and effect of RO (see, e.g., Andersson $\&$ Narus, 1991). More generally, previous research has recognized that value placed on relationships by the buying firm can vary considerably between industries (Anderson \& Narus, 1991; Heide \& John, 1992). In accordance with this reasoning, it would be 
interesting to investigate a bit further about the context factors that affect the relevance of $\mathrm{RO}$, and to develop some form of contingency model (cf. 'contingency model of salesperson effectiveness', Weitz, 1981). To really be able to sort this out and to better understand the mechanisms that influence whether products are launched successfully or not, in-depth empirical studies such as longitudinal case studies can be particularly appropriate. Responses from people involved in complex events can be quite biased and do not always represent reality. By studying a little more in depth, and preferably in realtime, what is really happening, the impact of such bias can be reduced. The findings by Matikainen et al. could serve as an excellent starting point for such study.

\section{The practical application of $\mathrm{RO}$ in sales}

Another addition to their study would be to further develop what RO really is, what it can mean in practice in a sales context, and to analyze if there are several variants of RO which may have different implications on the NPL success. In our opinion, it is likely that different variants fit more or less well in different contexts. In other words, assuming that $\mathrm{RO}$ can be beneficial in sales, further conceptualization of its practical meaning would seem essential. Matikainen et al. have just begun doing this and suggest that RO can be implemented in sales through SFM activities and RL. The activities related to managing the sales force refer to such elements as the composition of the sales force and its optimized size, adequate effort and commitment to new product, control issues, an incentive system, and internal marketing and training with regard to the launched product. The activities related to leveraging relationships described in the study are aiming at establishing and capitalizing relationships with key stakeholders. Such activities include identifying and involving opinion leaders, and building awareness of the product among key stakeholders prior to launch. Training, customer interaction, and involvement of opinion leaders are concrete examples of such activities.

We would suggest further studies investigating how these and other relevant sales activities work in practice and that someone look further into the prerequisites for the positive effects. Moreover, categorizing the activities depending on which specific 
stakeholder these are targeting, for instance users, buyers, influencers, decision makers, gatekeepers (Webster \& Wind, 1972), could prove helpful for managers in particular.

Furthermore, it would be interesting to figure out in which situations RO does not positively affect the success of NPL, or even have a negative effect on it. Parallels may be drawn to Cannon and Perreault (1999:454) who state that "closer relationships do not necessarily mean higher performance". To better understand the effects of RO, several performance and contingency variables are preferably be included in such a study. For instance, could it be that if the buyer's relationship focus is low then the seller's RO could even have a negative effect on NPL performance? Previous studies have contended that RO affects the seller performance positively as long as the benefits the buyer derives from the relationship management activities exceed the costs for the buyer to maintain the buyer-seller relationship (Palmatier, Scheer, Evans, \& Arnold, 2008). Further knowledge along these lines could be a fruitful way forward. Hence, the development of a contingency model for effectively implementing RO through activities conducted by the sales force (see, Weitz, 1981) and moderated by the buyer's RO (see, Palmatier et al., 2008) and other contingency variables in a NPL context could prove valuable.

\section{Conclusion}

Although the notion that adopting a relationship focus in sales and launching a product can have positive effects on the sales performance is not novel, the article by Matikainen et al. adds to this domain with their empirical study. More in detail, they conclude that a firm's RO, which is operationalized through the sales and relationship activities, positively relates to CA and success in NPL. Their article contributes with interesting new knowledge. In doing this, it also raises some questions that give us several ideas for several further studies. These further studies are either meant to better understand its practical meaning and effects, for instance how certain kinds of sales activities can influence different stakeholders, or to understand influences from context factors such as industry sector and market characteristics. Qualitative studies could suit well for the former and quantitative for the latter. 


\section{References}

Anderson, J. C., \& Narus, J. A. (1991). Partnering as a focused market strategy. California Management Review, 33(3), 95-113.

Borden, N. H. (1964). The concept of the marketing mix. Journal of advertising research, 4(2): 2-7.

Cannon, J. P., \& Perreault Jr., W. D. (1999). Buyer-seller relationships in business markets. Journal of Marketing Research, 36(4), 439-460.

Cooper, R. (1998). Benchmarking new product performance: Results of the best practices study. European Management Journal, 16(1), 1-17.

Di Benedetto, C. A. (1999). Identifying the key success factors in new product launch. Journal of Product Innovation Management, 16(6), 530-544.

Hultink, E. J., \& Atuahene-Gima, K. (2000). The effect of sales force adoption on new product selling performance. Journal of Product Innovation Management, 17(6), 435-450.

Langerak, F., Hultink, E. J., \& Robben, H. S. J. (2004). The impact of market orientation, product advantage, and launch proficiency on new product performance and organizational performance. Journal of Product Innovation Management, 21(2), 79-94.

Palmatier, R. W., Scheer, L. K., Evans, K. R., \& Arnold, T. J. (2008). Achieving relationship marketing effectiveness in business-to-business exchanges, Journal of the Academy of Marketing Science, 36(2), 174-190.

Webster Jr., F. E. \& Wind, Y. (1972). A General Model for Understanding Organizational Buying Behavior, Journal of Marketing, 36(April), 12-19.

Weitz, B. A. (1981). Effectiveness in Sales Interactions: A Contingency Framework, Journal of Marketing, 45(1), 85-103. 